\title{
Industrialization of the Manufacturing Sector and Trade Opening in Cameroon
}

\author{
Henri Ngoa Tabi \\ Director of the Center of Research and Studies in Economics and Management \\ Faculty of Economics and Management, University of Yaounde II \\ Tel:+237-9983-0672_E-mail: ngoa_henri@yahoo.fr \\ Henri Atangana Ondoa (Corresponding author) \\ Lecturer in the Faculty of Economics and Management \\ University of Yaounde II \\ Tel: +237-7778-6447Ｅ-mail: atanganaondoa@yahoo.fr
}

Received: November 22, $2010 \quad$ Accepted: January 4, $2011 \quad$ doi:10.5430/rwe.v2n1p58

\begin{abstract}
In this paper, the authors investigate the effect of trade opening on the industrialization of the manufacturing sector in Cameroon using the error correction model. The study uses data from the World Bank in the period 1967-2007. Our findings show that the long-term relationship between trade opening and industrialization of the manufacturing sector is not stable and that trade opening negatively affects the manufacturing sector of Cameroon. This result is explained by the fact that importations of some food products and inputs cannot be reduced. Moreover, Cameroon manufacturing enterprises are apparently unable to satisfy domestic demand.
\end{abstract}

Keywords: Industry, Exportations, Importations, Trade opening

\section{Introduction}

No country can possibly develop without a high-technology industry. In fact, it is the industrial sector that produces most of the goods and services in developed countries. This is because the secondary sector is highly mechanized and adapts easily to technological changes. Thanks to the multiplier effect of industrial equipments and productivity improvements which are generated, machines permit us to produce more with less labour and this way, we can then grow rich; since labour is finally the source of every value added. In the 2008 report of the United Nations Conference on Trade and Development (UNCTAD) based on least developed countries (LDC), it is highlighted that the dependency of poor countries on basic products has increased for the past years. The percentage contribution of raw materials in total exports of goods has increased from $59 \%$ in the period 2000-2002 to $77 \%$ in the period 2005-2006. One may say the development of industry in developing countries accuses some lateness.

In Cameroon for instance, the contribution of the industrial sector to GDP (Gross Domestic Product) is well below that of the tertiary sector (see figure 1). This situation is explained by a number of structural problems. In 2008, the Cameroon Ministry of Finance carried out a study on the competitiveness of manufacturing industries using 95 enterprises grouped in 13 branches. Findings from this study show that unit costs of enterprises are considerably high. Inputs constitute the main component of the general costs of manufacturing industries $(77,2 \%)$, followed by the cost of capital (10,1\%), cost of labour (9,2\%) and taxes (Note 1) (MINFI, 2009a). Moreover, Cameroonian industrialists are often faced with problems of smuggling, unfair competition, high tax rates and bad governance.

These observations come at a time when Cameroon as other ACP countries signs free trade agreements with the European Union. In this light, this study examines the impact of trade opening on the industrialization of manufacturing sector (Note 2) in Cameroon. Indeed, trade opening may have two contradictory effects on the industrialization of a country. It may reduce prices of imports as well as reduce inefficiency within enterprises, as enterprises are exposed to foreign competition. This study attempts to examine the net effect of trade opening on industrialization of manufacturing in Cameroon. To do this, the work is organized as follows: section 1 presents industrial production and trade opening in Cameroon; section two exposes the theories of industrialization; section three analyses the models of industrialization in Cameroon, sections four and five develop respectively the methodology and the results of the study. 


\section{Industrial Production and Trade Opening in Cameroon}

\subsection{Industrial production}

In Cameroon, the secondary sector is made up of five main categories of industries. These categories include: mining and oil refining industry; agro-industry; wood processing industry and textile industry (other industries); energy and water; buildings and public works (BPW).

The mining and oil refining industry has observed a downward trend since 2007 because of the drying up of main operational wells. Besides, this sub-branch of industry is the one which undergoes most external shocks. In 2009, the revenue of petroleum oil exports fell by $39 \%$. On the other hand, the quantity of petroleum oil exports declined by $4 \%$ and 13,1 \% in 2008 (MINEPLAT, 2010). From 1993 to 2008, the value added of this sub-sector dropped from 821,61 billions FCFA to 500,25 billions FCFA (see graph 2). At this level, it is important to note that the main exported product is oil, but Cameroon also possesses bauxite, diamond, and uranium. It is also important to note that the reserves of gas amount to 110 billion cubic meters (WTO, 2001).

The agro-industry is dominated by the production of the following products; sugar, flour, refined oil, brewery and soap products. This sub-sector has observed a relative expansion because its products are consumed by Cameroonians. Specifically, the production and the turnover of agro-brewery industries have increased respectively by $14 \%$ and $19,1 \%$; for wheat, the volume produced and the sales have increased respectively by $9,4 \%$ and $8,5 \%$ in 2009 (MINFI, 2010). From 1993 to 2008, the value added of this sub-sector has passed from 304,10 billions FCFA to 525,91 billions FCFA (see graphic 2).

In the sub-sector of other industries (wood transformation and textile industry), the production of by-products of wood suffered the effects of the 2008 global crisis. This way, the quantity of sawed wood fell by $38 \%$ in 2009 , notably because of the shortfall in demand in the international market. The textile industry experienced on the other hand an activity surge of $10,3 \%$ in 2009 , due to increase sales of factual loincloths, particularly those used for the visit of the Pope in March, 2009 (MINEPLAT, 2010). Between 1993s and 2008, the value added of wood processing industries and textile industry passed from 566,47 billions FCFA to 961,39 billions FCFA (see graphic 2).

In the sub-sector of energy and water, the production of electricity fell by $0,3 \%$ in 2009 . This decline is explained by the decline of $2,5 \%$ in hydraulic production which was not compensated by the increase in thermal production $(38,1 \%)$ thanks to the two new thermal power factories. But, in 2010, electricity production should increase in Cameroon due to renovation and rehabilitation works of the hydroelectric power factory of Edéa. The production of water fell by $2 \%$ in 2009 because of unfavourable climatic conditions. The government of Cameroon intends, in 2010, to build waters processing factories in the suburbs of Yaoundé and Douala. These new factories will raise the production of water to 165 $000 \mathrm{~m} 3 /$ day in the economic capital ( Douala) and to $150000 \mathrm{~m} 3 /$ day in Yaoundé. Combined with the other works of rehabilitation, extension and densification of the system of supply, the rate of water supply should pass from $35 \%$ to $60 \%$ at the national level in 2015 (MINEPLAT, 2010). From 1993 to 2008, the value added of the sub-sector hardly doubled as it passed from 38,41 billions FCFA to 67,28 billions FCFA (see graphic 2).

Concerning buildings and public works, this sub-sector has observed a surge in her activity as a result of the improvement of inputs supply. Indeed, the improvements in the production capacities of cement as well as the increase of import quota have permitted to reduce the deficit of cement. The production and the sale of cement recorded respectively an upswing of 26,5\% and 12,2 \% between 2008 and 2009. In 2010, the cement factory of Cameroon envisages to increase production to about $13,8 \%$. For demand, the continuous construction of road and real estate, the construction of the Lom Pangar dam and the deep sea port in Kribi allows us to expect a favourable evolution of activities in this sub-sector (MINEPLAT, 2010).

$<$ Figure 1 and 2 about here $>$

\subsection{Trade opening}

Trade opening, generally estimated as a ratio of total imports and exports on GDP, is integrated into the decision menu of trade policy in Cameroon. In fact, the Cameroonian government has taken important measures to liberalize the regime of trade policy, promote the development of the private sector as an engine of economic growth, strengthen the competitiveness of the country and to boost investment (WTO, 2001).

Concretely, trade opening is highlighted by a strong increase of imports and a stagnation of the volume of exports. In effect, foreign trade registers a permanent increase of imports, especially of manufactured and food products and quasi stable exports for a few number of primary products. This evolution has led to a deficit of 268,2 billions FCFA in 2008, which indicates an increase of 199,2 billions FCFA as compared to 2007. In the same period, the exchange deficit, 
except oil, deteriorated passing from 290,7 billions FCFA in 2007 to 712,6 billions FCFA in 2008. Generally, the observed increase in the value of imports is explained by a steady increase in import prices. Specifically, the main products imported in 2008 were: food products which represented 18,2 \% of total imports. These products have witnessed an increased of $35,1 \%$ accounting to about 463,4 billions FCFA mainly due to frozen fish (31,3\%), milk $(22,2 \%)$, rice $(28,5 \%)$, refined palm oils $(38,8 \%)$ and food preparations with cereal $(36,8 \%)$. Machines and mechanical or electric appliances represented $12 \%$ of the total value of imports, and recorded an increase of $13,2 \%$ in 2009. In the same period, exports remained stable in volume, about $0,2 \%$ between 2007 and 2008 and amounted to about 2271 billions FCFA with 1115 billions FCFA for oil (INS, 2009).

The exports of goods increased by $1,1 \%$ and those of services fell by $6,1 \%$. In 2009, the decline of oil production and world prices provoked a downswing in crude oil exports, which is the main exported product (MINFI, 2010). Cameroon exportations also include wood (335, 1 billions FCFA in 2007 in terms of export revenue); cocoa (140, 8 billions FCFA in 2008); wood (33, 5 billions FCFA in 2008); rubber (30 billions FCFA in 2008), and coffee (MINEPLAT, 2010a). We can observe that export revenues are mainly generated by wood, cocoa and coffee.

\section{Theories of Industrialization and Strategies of Industrialization}

Many controversial arguments are raised on how to develop an industry. We have for example the debate on the distribution of investments between sectors or that on the strategies of industrialization.

\subsection{The theories of balanced / unbalanced growth}

Concerning the distribution of investments between activity sectors, Rosenstein-Rodan (1943) in his theory of the big-push proposes an all azimuth investment program. This supporter of balanced or proportionate growth supports the idea that the solution to develop poor countries would be to invest massively, via international assistance, to generate an important volume of externalities within an economy. According to him, development is not only an educational, health or infrastructural issue, but all these together, since what makes the whole to function is the external effects and the generated increasing returns. What matters beyond anteriority of investments are the simultaneity and the synergy of investments. For Nurkse (1953), the concentration of investments in a single sector cannot develop an industry because the demand for products of this industry would be low. An investment in a single sector cannot build its own demand and cannot develop the domestic market.

Despite its attractiveness, this theory was nevertheless criticized by supporters of the unbalanced growth. In fact, developed countries are not also endowed with resources to be able to solve all the development problems in the South. According to Hirschman ( 1958 ), the theory of the big-push is an advice for the hopeless, how can we ask developing countries without real industries because of the lack of financial and human resources to invest in all the activity sectors, or not to invest at all. For him, nations have to concentrate their resources in key sectors during the first phases of development. Besides, non-competitive countries are organically connected to a fast growth. Analogically, investment introduced by the State should attempt to establish non-proportionality growth poles, as unequal opportunity would stimulate competition and thus private initiative (Perroux, 1969).

Using a cross country model, Puga and Venables $(1998,1999)$ describes the process of development as waves of fast industrialization where the industry spreads successively from one country to other. Originally, the development of industry in a country has as consequence to increase its salary with respect to other underdeveloped countries. Beyond a certain threshold, the wage gap stimulates the relocation of a portion of the industry towards a peripheral country in which upstream-downstream relations insure the continuation of the process of industrialization. From the first industrialised countries, an increase in the wage gap with other countries follows, this way; the process of fast industrialization then spreads from one country to the other.

\subsection{The types of strategies}

We distinguish traditionally three strategies of industrialization.

\subsubsection{Industrialization by the substitution of import}

This strategy has as objective to provide the internal market with drinks, foodstuffs and clothes. It implies, to substitute imported goods by locally produced goods to reduce the dependency on imported products and to diversify the productive capacity step by step, increasing production sectors. Industrialization is done in a gradual way and passes through four main stages. In the first stage, accent is put on "light" industry which requires a low technology. In the second stage, we pass to "heavy" industry, the case of textile industry and chemical product industry. In the third stage, the authorities develop equipment sectors such as electrical manufacturing and industrial factories. In the last stage, resources must be mobilized towards the sector that produces sustainable consumption goods such as cars and planes 
(Watson, 1991; Buzenot, 2009). This policy of imports substitution in the 1960s and 1970s shielded state-owned enterprises from foreign competitors, and compromised at the same time their efficiency and their competitiveness on the international market (Teal, on 1999).

\subsubsection{Industrialization by the substitution of exports}

This strategy consists to substitute gradually traditional exports by non traditional exports for example transformed primary products, semi-manufactured goods, and industrial products. It considers comparative advantage in natural resources, in cost and not a classical or neo-classical understanding of specialization. Indeed, all these come from a sequence of movements capable of generating new exports where the State and the market play successively a dominant role (Akamatsu, 1950). This strategy presents many advantages; the division of labour is limited by the extent of the market. But, developing countries rarely have a vast internal market to permit a specialization plan that leads to an effective allocation of resources. The world market does not only constitute an optimal possibility for small countries to specialize in a portion of the market, but it also gives them the opportunity to benefit from effects of scale in their production. However, exposing a country to international competition, increases generally her technological efficiency, which in return generates growth. Productivity can also improve due to acquisition of knowledge which accompanies all activities of export, since we learn by exporting (Magariños, 2003).

\subsubsection{Industrialising industries}

It consists to develop some industries which will have a strong effect on the formation of other industries. Priority is given to heavy industries which take advantage of downstream relations. Expensive investments impose a strong intervention of the State; planning and nationalization of enterprises for examples. The aim of this model is to focus more on intersector-based auto-centring than intra-industrial, as in the previous case (Bernis, 1982).

\section{Models of Industrialization in Cameroon and Some African Countries}

\subsection{Attraction of Foreign Direct Investments (FDI)}

FDI in Africa is mainly from multinational enterprises and the government of Cameroon attracts these multinationals because they bring-in capital to compensate the insufficiency of domestic savings. FDI made a marked headway at the beginning of the 1990s with the increasing importance of liberal policies with the withdrawal of States involvement in the production sphere. In this perspective, many privatized public enterprises were given up to western multinationals. Moreover, these enterprises are particularly interested in the exploitation of natural resources like oil, wood, energy and iron. In 2002, countries that attracted the highest FDI were, in ascending order: Angola, Nigeria, Chad, South Africa and Mozambique. In 2004, FDI flows, as a percentage of gross fixed capital formation, represented approximately $200 \%$ of gross national product in Equatorial Guinea. FDI remained dominant in the petroleum industry in 2002 with Angola, Algeria, Chad, Nigeria and Tunisia representing more than half of the total flows in 2002. In 2002, Egypt, Angola, Nigeria and South Africa received a proportion of $61,9 \%$ of FDI; with the coming of Tunisia in this group, its proportion has gone up to 70,11\%. Foreign direct investment in Africa has doubled between 2004 and 2006 to reach 36 billion dollars. According to UNCTAD (2008a), this evolution is explained by the attraction of primary resources, the increase in profits of enterprises and generally by a more favourable economic climate. In Cameroon, all the big structuring projects (energy, water, deep sea port, and railroad) would be financed mainly by China, France and some multilateral barkers like the ADB. To strengthen the sub-sector of mining, the government of Cameroon intends to attract FDI using measures such as: grant the possibility to companies that exploit hydrocarbons to import, duty free, all equipments and material and the liberalization of pump prices; the parliament voted in April, 1998, a law on fiscal incentives (exemption of special tax on income) for exploitation and implementation of oil-fields and the reduction of tariff protection (WTO, 2001)

\subsection{Vertical diversification}

Following the example of Cameroon, Ivory Coast and Senegal some African countries have opted for vertical diversification with the aim to overcome their vulnerability with respect to high volatility of raw materials prices. However, vertical diversification allows a country to obtain the normal advantages of industrialization (better economic relations, better employment prospects, better productivity, etc.) by exploiting raw materials available and a relatively good knowledge of the derived products in the international market. But, for Cramer (2003), these expectations have turned out to be less promising in Black Africa due low level technology, narrow domestic markets and problems of integration of countries in the continent. However, the author observes some good results, particularly in Ivory Coast (fishing and drinks) and Senegal (fishing). It appears that these successes are strictly connected to effective policies implemented to promote diversification. 


\subsection{The promotion of clusters or groups of enterprises}

The grouping of many enterprises in the same site favours the exchange of information and sharing of experiences. With time, it can also encourage specialization in given aspects of the process of production or incite some enterprises to focus more on activities or related services. Their environment is also modified. Clusters attract customers, traders, qualified workers, suppliers of goods and services, and new enterprises that want to benefit from the market so created. The relations that govern these enterprises may favour the putting in place of new institutions or modify the already existing institutions (Mccormick, 2003). Examples of industrial clusters abound in East Africa. We have: Eastlands a group of about 600 small firms of clothing business in two markets in big Nairobi. Their outlets are national: Nairobi and remote cities; Kamukunji a group of about 2000 metallurgical workshops in the border of Nairobi; Ziwani: a group of automobile mechanics workshops producing spare parts (internal side dishes, rubber rings, etc.). It is made up of about 500 workshops, with $6 \%$ in the sector of manufacturing; Western Cape: a big textile group with more than 500 different-sized enterprisess, with their suppliers and their distributors (Mccormick, 2001).

\subsection{The promotion of SME (Small and Medium-Sized Enterprises)}

With globalization, SME in Africa face competition from Asian and European enterprises. More to that, the lending rate supported by SME is generally higher than the lending rate of banks to big enterprises. This way, ACP countries and EU have conceived and implemented a strategy to assist the private sector. This strategy is based on four pillars. 1) The creation of a convenient environment to free-enterprise. It entails the definition of a legal, regulatory and institutional framework within which ACP enterprises will evolve. 2) The modernization of economic infrastructures. It implies encouraging the private sector to undertake and finance public works. 3) The intensification of support Institutions highlighted by an appropriate support to professional organizations and national and regional financial institutions that work with SME, through capacity building and financial support. 4) Financial, material and human support to SME (Oliveira, 2003). In September, 2009, the government of Cameroon granted a subsidy of 11 billions FCFA to SME in all the ten regions of the country that work in the transformation and preservation of local products of mass consumption. This program will favour the creation of about 3500 direct jobs and will substantially reduce the losses that normally come after harvests (MINFI, 2010).

\subsection{The promotion of good governance}

Cameroonian enterprises still support heavy regulatory and administrative constraints than other regions, and property rights and investors' rights are not well protected in the country. Cameroonian authorities have put an accent on the facilitation of enterprise creation, trade opening, fight against corruption and reduction of importation and exportation cost (World Bank, 2009). According to the World Economic Forum report's on the global competitiveness in 2009, Cameroon was classified 18th in Africa and 111th in the world on a total of 133 countries. The most considerable efforts were observed at the level of macroeconomic stability (34th), recruitment and firing (40th), flexibility of salaries (61th) and transparency of the government in driving economic policy (76th). However, more efforts should be mobilised with respect to the improvement of Institutions (112th); bureaucratic efficiency of the Government (102nd); " access to financing " (125th) and the quality of infrastructures (121th) which are important for investment (MINFI, 2010).

\section{Methodology}

To assess the effect of trade opening on industrialization of the manufactured sector in Cameroon, we are going to employ an error correction model. In a short-term dynamics, we can suppose that at period $t$, trade opening (X) and the amount of credit granted to the private sector (Y) affect the level of industrialization (Ind) of the country as specified in equation (1). In this sense we can orientate industrialization strategies to the transformation of local products in order to reduce the vulnerability of economies (Cramer, 2003). We can observe that the three types of industrialization analyzed above have net effects on the degree of opening of an economy. This is so because an industry develops partially because its products and its services are demanded. However, the cost of money or interest rate determines the production cost of enterprises. In fact, big enterprises in Cameroon; which are mostly branches of western multinationals, are more transparent in their management through the production of reliable information, support a lower level of customer risk and in return a lower cost of credit than private individuals and SME (Shepherd, Frame and Miller, 2005). Making average costs of credit in Cameroon for big enterprises to stand at 9,19\%; 13,86 \% for SME and $17,17 \%$ for private individuals. Besides, in Cameroon, over-liquidity is observed along side unsatisfied financing needs of enterprises (less than 0,40\% of credits was granted in the long-term between 2002 and 2005 in Cameroon). Banks prefer short-term services (overdraft, transfer, commission on foreign-exchange transactions...) and investments at the BEAC. The reasons raised are the volatility of resources, absence of bankable projects, judicial insecurity and illegibility of enterprises which cannot provide the enormous guarantees demanded (Wanda, 2007). 
Therefore, we can consider that at period t, the level of industrialization of the manufactured sector ( ind ) in the country can be explained among other factors by trade opening (X), amount of credit granted to the private sector and the error term $\mathrm{v}$ which captures the influence of other variables not included in equation (1).

$$
\text { Ind }_{t}=\beta_{0}+\beta_{1} x_{t}+\beta_{2} y_{t}+v_{t}
$$

If the estimated residuals in equation (1) are stationary, then equation (1) translates a dynamic long-term equilibrium and all the variables (Note 3) of the model are affected by the same trend. On the other hand, if the estimated residuals are not stationary, equation (1) should be rejected. However, these residuals are not stationary as indicated in figure (1). Moreover, the diagnostic tests are all significant whereas all the variables are significant, implying the presence of a deceptive regression. It is so because the residue of equation (1) is supposed to capture the influences of exogenous variables on the long-term endogenous variable while the estimated coefficients specify the short-term effects. For that purpose, it is advisable to study the model with error correction which leans on the approach of Engle and Granger (1987). Indeed, a stationary linear combination of $\mathrm{n}$ variables is called the equation of cointegration and can be interpreted as a length-term equilibrium relation between the $n$ variables. The presence of a cointegration relation constitutes the basis for the specification of the error correction which consists to propose in an integrated model a static representation which is a long-term component (cointegration relation) and a short-term dynamic representation (adjustment of the component).

$<$ Figure 3 about here $>$

Therefore, the error correction model employ in this study is as follows:

$$
\Delta \text { Ind }_{t}=\phi+\sum_{i=1}^{k_{1}} \Delta \text { Ind }_{t-i}+\sum_{i=0}^{k_{2}} \beta_{i} \Delta x_{t-i}+\sum_{j=0}^{k_{3}} \beta_{j} \Delta y_{t-j}+\beta_{0} E C M_{t-1}+\varepsilon_{t}
$$

In equation (2), $\mathrm{B}$ and $\quad \phi \quad$ are parameters to be estimated, $\mathrm{k}$ the number of lags for each variable $\mathrm{i}$ or $\mathrm{j} ; \varepsilon_{t}$ the error term ; ECM the estimated residuals of equation (1). These residuals represent all deviations around the long-term equilibrium. The difference of order $\mathrm{k}$ represents movements around the short term equilibrium.

\title{
5.1 Data
}

$<$ Table 1 about here $>$

The evolution of estimated residuals presents strong peaks for 1977s, 1980, 1981, 19982, 1985, 1993, 1996 (see figure 3). These peaks translate deviations around the long term equilibrium. To correct these disequilibria and improve the quality of inferences, dummy variables (taking the value 1 or -1) were created for each of these years.

\subsection{Determination of the number of lags for the two exogenous variables of equation (2)}

$<$ Table 2 about here $>$

Setting the exogenous variables of equation 2 in the order k, we specify the effects of lagged exogenous variables on the movements around the short-term equilibrium. This way, the test of Fisher is used to determine the order. This test was done using the PcGive 12 software and the results of the test show that any integration order greater than 1 should be rejected (see table 3).

\section{The Findings of the Study}

\author{
$<$ Table 3 about here $>$ \\ $<$ Table 4 about here $>$
}

The estimated coefficient of the residue is significant and has a negative sign, translating therefore a certain divergence around the long-term equilibrium. However, the level of industrialization of manufacturing decreases with short-term trade opening following the results of this study. Reason being that, Cameroonian enterprises are less competitive and so, cannot face the competition from Asian and European products. Besides, the private sector operators often complain of the level of fiscal pressure as well as smuggling.

On another aspect, the insertion of the Cameroonian economy to the world market is certainly going to bring numerous opportunities in terms of market diversification, access to technologies and foreign direct investments (FDI), but it also exposes the economy to negative effects of external shocks and crises. In fact, the advantages gained from trade opening are very limited because the structure of exchange of the country determines the potential scale of trade opening benefits. This opening amplifies especially negative effects connected to external shocks. Analysis of the structure of exchange with the outside world highlights two major issues: 
$>\quad$ The predominance of exports of primary products (aluminum, rubber, banana, wood, cocoa, coffee, cotton) at the detriment of manufactured goods. Raw materials which are the main exported goods expose Cameroon to a strong variation of terms of exchange, a strong income and foreign trade vulnerability. Foreign trade fluctuations being a function of costs of exported products which are determined by the international market.

$>\quad$ The relatively important weight of imported household consumption goods reduces the benefits of trade opening in Cameroon. In fact, the structure of imports reveals the incompressible character of majority of imported products particularly foodstuffs, finished products (essentially equipments and some factors of production) and energy products. We observe a dependency on the outside world for products considered as basic necessities and compulsory for the country's growth. Consequently, Cameroon undergoes supports any price increase of these products given the impossibility to reduce the imported quantities. Hence, a steady tendency tends to increase the level of imports.

Moreover, the level of industrialization of manufacturing is negatively affected by the amount of credit granted to the private sector. This result more or less intuitively explained by the effect of money supply on the general level of prices. Indeed, when money supply increases, the general level of prices also increases, which affects general competitiveness of the economy. This is so because, according to the MINFI ( 2010 ) economic growth remains supported by domestic demand with a contribution of about $6,3 \%$ in 2008, following the increase in household consumption; stimulated by the increase in salaries and the numbers of workers in public administration. Gross investments also supported the demand thanks to the intensification of infrastructures improvement programs, acquisition and renewal of production instruments in the electricity sectors, water and manufacturing industries. Therefore, an increase in the money supply through credit granted to the private sector should inflate the level of prices which affect negatively the competitiveness of the industrial sector of Cameroon in the short-term.

\section{Conclusion}

Using data from the World Bank, this study finds that trade opening is harmful for the competitiveness of the manufacturing sector in the short and long-term in Cameroon and that any increase in the money supply can induce a general price increase. For that purpose, at a time when ACP states are preparing to sign free exchange agreements with the European Union, it is more than ever important for Cameroonian authorities to define and apply a strategy of restructuring of enterprises and especially to build a strategy of economic relaunch based on supply and not on demand.

\section{References}

BEAC (2009) Note de conjoncture économique, Comité monétaire et financier national (CMFN), Yaoundé.

Bratton, M., \& Rothchild, D. (1992). Bases institutionnelles de la gouvernance en Afrique, Gouverner l'Afrique, Nouveaux Horizons, Paris, Le Seuil, 2001.

Berger A., Frame W., \& Miller N., (2005) Credit Scoring and the Availability, Price, and Risk of Small Business Credit, Journal of Money, Credit, and Banking, 37, (37), 191-222. doi:10.1353/mcb.2005.0019, http://dx.doi.org/10.1353/mcb.2005.0019

Buzenot, L., (2009) Les zones franches industrielles d'exportation dans la Caraïbe. Les causes économiques de leur Emergence, Etudes Caribéennes, 13 (14),1-28.

Carret, J. (1999) L'industrialisation de la filière bois au Cameroun entre 1994 et 1998 Observations, Interprétations, Conjectures, [online], available: http://www.cerna.ensmp.fr/Documents/JCC-Synthese.pdf

CEA (2010) Rapport économique sur l'Afrique 2010, Addis Abéba, [online], available: http://www.ilo.org/public/english/region/afpro/addisababa/pdf/era_2010_fr.pdf (septembre 2010)

CNUCED (2008). Le rapport 2008 de la CNUCED sur les pays les moins avancés (PMA), croissance, pauvreté et modalités du partenariat pour le développement, [online], available:

http://www.gipspsi.org/GIP_FR/content/download/4748/41500/version/1/file/CNUCED\%202008.

CNUCED (2008a). Les tendances en matière d'investissements, Bureau de presse de l'ONU.

Cramer, C. (2003). Faut-il favoriser la transformation, Le Courrier ACP-UE , 196, 30-32.

David, T., \& Goertz, G. (2000). Les positions industrielles de I'Europe à la veille de la seconde guerre mondiale , Revue Economique, 51, (2), 213-227. doi:10.2307/3503118, http://dx.doi.org/10.2307/3503118 
Gills, D., Perkins, S., Radelet, Roemer, M., \& Snodgras, R. (2001). Economics of Development, (5 ${ }^{\text {ième }}$ edit), Norton and company.

FMI (2007) Etudes économiques et financiers: perspectives économiques régionales, Afrique Subsaharienne, [online], available : www.imf.org/external/pubs/ft/reo/2007/afr/fra/afrf.pdf (mai, 2007)

Ibi, Ajayi, S. (2006). L'IDE et le développement économique en Afrique, [online], available: www.afdb.org/.../09484246-FR-FDI-AND-ECONOMIC-GROWTH1-FR-EDIT.PDF - INS (2009), Les Comptes Nationaux du Cameroun, (Deuxième édition), Yaoundé.

Hirschman, A. (1958). The strategy of economic development, Yale University Press, New Haven.

Kaufmann, D., Kraay, A., \& Zoido-Lobaton, P. (2008). Governance matters, World Bank Policy Research WP 2196.

Oliveira, E. (2003). Les multinationales et les pays en voie de développement : puissance commerciale et pauvreté, Le Courrier ACP-UE, 196, 36-38.

OMC (2001) Examen des politiques commerciales, Cameroun 2001, Centre william Rappard, rue de Lausane 154, 1211, Genève 21, Suise.

Madeley, J. (2003). La promotion des PME dans les pays ACP dans le contexte du développement industriel, Le Courrier ACP-UE , 196, 42-44.

Magariños, C. (2003) Le Courrier ACP-UE $n^{\circ}$ 196, PP 42-44.

McCormick, D. (2001). Enterprise Clusters in Kenya : Urban Production,Upgrading Strategies, and Joint Action , Africa Insight, (31) 1, 3-11.

Mccormick, D., (2003). Faut-il favoriser les Cluster industriels en Afrique?, $\quad$ Le Courrier ACP-UE, 196, $33-35$

MINFI (2009), Programme Economique, Financier, Social et Culturel du Gouvernement au titre de l'exercice 2009, Yaoundé.

MINFI (2009a). Compétitivité des entreprises du secteur manufacturier au Cameroun, rapport pricipal, Yaoundé.

MINFI, (2010), Programme Economique, Financier, Social et Culturel du Gouvernement au titre de l'exercice 2010, Yaoundé.

MINEPLAT (2010). Perspective de l'économie camerounaise : l'économie camerounaise dans le contexte de la reprise de l'économie mondiale, division des analyses et des politiques économiques, Yaoundé.

MINEPLAT (2010a) Etude sur les mesures de soutien à la balance courante du Cameroun, Yaoundé.

Murphy, Shleifer A., \& Vishny, R. ( 1989). Industrialization and the Big Push, Journal of Political Economy, 2 (4), $22-54$.

Perroux, F.(1955). Note sur la notion de pôle de croissance, Economie Appliquée, 1(2), 307-320.

Perroux F. (1969). L'économie du vingtième siècle, Paris, PUF, 3 é édi.

PNUD (2008). Rapport 2008 sur les OMD, [online], available: www.un.org/fr/millenniumgoals/pdf/mdg2008

Puga D. (1999) The rise and fall of regional inequalities, European Economic Review, 43(2), $303-334$. doi:10.1016/S0014-2921(98)00061-0, http://dx.doi.org/10.1016/S0014-2921(98)00061-0

Puga D., \& Venables, A. (1998). Trading arrangements and industrial development? World Bank Economic Review, 12 (2), 221-249.

Puga D., \& Venables, A. (1999). Agglomeration and economic development: import substitution vs. trade liberalisation, Economic Journal, 109 (455), 292-311. doi:10.1111/1468-0297.00433, http://dx.doi.org/10.1111/1468-0297.00433

Rosenstein-Ridan, P. (1943). Problems of industrialization of Eastern and South- Eastern Europe, Economic Journal, 53 (1), 202-211. doi:10.2307/2226317, http://dx.doi.org/10.2307/2226317

Teal, F. (1999). The Ghanaian manufacturing sector 1991-1995: firm growth, productivity and convergence, Journal of Development Studies, 36 (2), 109-127. doi:10.1080/00220389908422614,

http://dx.doi.org/10.1080/00220389908422614

Wanda, R. (2007). Risques, comportements Bancaires et déterminants de la surliquidité, Cahier électronique du CRECCI. 
World Bank (2007), Africa Development indicators, [online], available:

http://siteresources.worldbank.org/AFRICAEXT/Resources/english_essay_adi2010

World Bank, (2009), Doing Business 2009, 1818 H Street NW, Washington, DC 20433, [online], available: www.doingbusiness.org

Notes

Note 1. However, some branches are competitive with respect to the evolution of the main criteria of competitiveness (unit cost, apparent productivity and net exports). They include "diverse Manufacturing industries ", "Basic metallurgy industries", " Chemical industries and manufacturing of chemical products ", " agricultural products Processing industries ", and "Industries of rubber and plastic ". On the other hand, the least competitive branches include: "manufacturing of mechanical and electric devices ", " Industries of papers and papers products" and " Manufacturing of drinks and tobacco ". The sector of " Wood and wood products like furniture ", a net exporter with a high labour-intensity who has registered steady growth of the added value (MINFI, 2009a).

Note 2. Our study is based only on manufacturing because industrial enterprises of this sector undergo more foreign competition.

Note 3. To stabilise the variance, all the variables are expressed in log form.

Table 1. Data used in the study

\begin{tabular}{|c|l|}
\hline Variable & \multicolumn{1}{c|}{ Explanation } \\
\hline Ind & $\begin{array}{l}\text { Industrialisation of the manufactured sector measured by the ratio } \\
\text { of the value of the manufactured sector to GDP }\end{array}$ \\
\hline $\mathrm{X}$ & Trade opening captured by the ratio of exports + imports to GDP \\
\hline $\mathrm{y}$ & $\begin{array}{l}\text { Amount of credit granted by banks to the private sector as a } \\
\text { percentage of GDP }\end{array}$ \\
\hline $\begin{array}{l}\text { All variables are expressed in log. In this form the variables are stationary after } \\
\text { the ADF tests. }\end{array}$
\end{tabular}

Data is obtained from the World Bank for the period 1967-2007.

Table 2. Tests to determine the number of lags

\begin{tabular}{|c|c|c|}
\hline Lag 3 & $\mathrm{~F}(1,30)$ & $=0.83872[0.3671]$ \\
\hline Lag 2 & $\mathrm{~F}(2,30)$ & $1.6008[0.2185]$ \\
\hline Lag 1 & $\mathrm{~F}(3,30)$ & $8.2936[0.0004]$ \\
\hline \multicolumn{3}{|c|}{ Tests on the significance of all lags up to 3} \\
\hline Lag $3-3$ & $\mathrm{~F}(1,30)$ & $=0.83872[0.3671]$ \\
\hline Lag 2 - 3 & $\mathrm{~F}(3,30)$ & $=1.3504[0.2768]$ \\
\hline Lag $1-3$ & $\mathrm{~F}(6,30)$ & $4.4501[0.0025]$ \\
\hline \multicolumn{3}{|c|}{ Tests on the significance of all lags up to 2} \\
\hline Lag 2 - 2 & $\mathrm{~F}(2,30)$ & $1.6008[0.2185]$ \\
\hline Lag $1-2$ & $\mathrm{~F}(5,30)$ & $5.1244[0.0016]$ \\
\hline
\end{tabular}

Source: authors' estimation using data from the World Bank 
Table 3. Estimation results

\begin{tabular}{|c|c|c|c|}
\hline Variables & Coefficient & Std-deviation & $t$-prob \\
\hline Indus of manufactured sector ( 1) & 0.391727 & 0.01263 & 0.02409 \\
\hline Trade opening & -0.107950 & 0.02275 & 0.0172 \\
\hline Credit to private sector & -0.0964796 & 0.09487 & 0.3185 \\
\hline Residual & -0.193770 & 0.03925 & 0.0257 \\
\hline dumm1977 & -0.152121 & 0.03987 & 0.0008 \\
\hline dumm1982 & 0.131843 & 0.03978 & 0.0027 \\
\hline dumm1980 & 0.163760 & 0.04016 & 0.0004 \\
\hline dumm1981 dumm1985 & 0.0955232 & 0.04492 & 0.0431 \\
\hline dumm1993 & -0.0604816 & 0.04396 & 0.1806 \\
\hline dumm1996 & 0.345927 & 0.08403 & 0.0003 \\
\hline Constant & -0.0720399 & 0.04143 & 0.0939 \\
\hline $\begin{array}{l}\text { Sigma: } 0.0380202 \\
\text { RSS: } 0.0375839877\end{array}$ & -0.0054931 & 0.00711 & 0.09391 \\
\hline $\begin{array}{l}\text { R`2: } 0.9174911 \\
\text { F(11,26) }=16.53[0.000] * * \\
\text { Number of observations:38 }\end{array}$ & & & \\
\hline \multicolumn{2}{|l}{} & & \\
\hline
\end{tabular}

Source: authors' estimation using data from the World Bank

Table 4. Diagnostic tests

\begin{tabular}{|lccc|}
\hline AR 1-2 test: & $\mathrm{F}(2,24)$ & $=$ & $2.1031[0.1440]$ \\
\hline ARCH 1-1 test: & $\mathrm{F}(1,24)$ & $=0.060136[0.8084]$ \\
\hline Normality test: & $\mathrm{Chi}^{\wedge} 2(2)$ & $=$ & $2.5285[0.2825]$ \\
\hline Hetero test: & $\mathrm{F}(15,10)$ & $=$ & $0.24819[0.9923]$ \\
\hline RESET test: & $\mathrm{F}(1,25)$ & $=$ & $1.9078[0.1794]$ \\
\hline
\end{tabular}

Source: authors' estimation using data from the World Bank

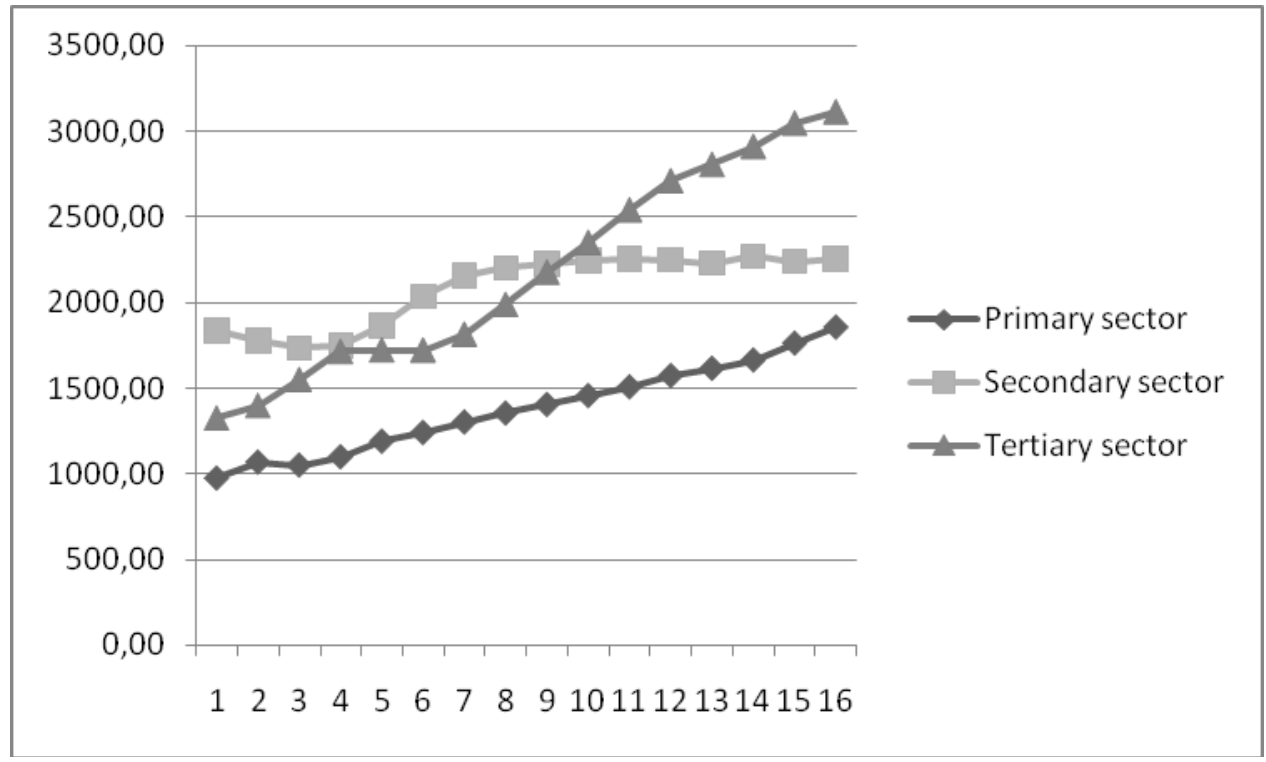

Figure 1. Evolution of sector contribution to GDP between 1993 and 2008

Source : constructed by author using data from the NIS (2009) 


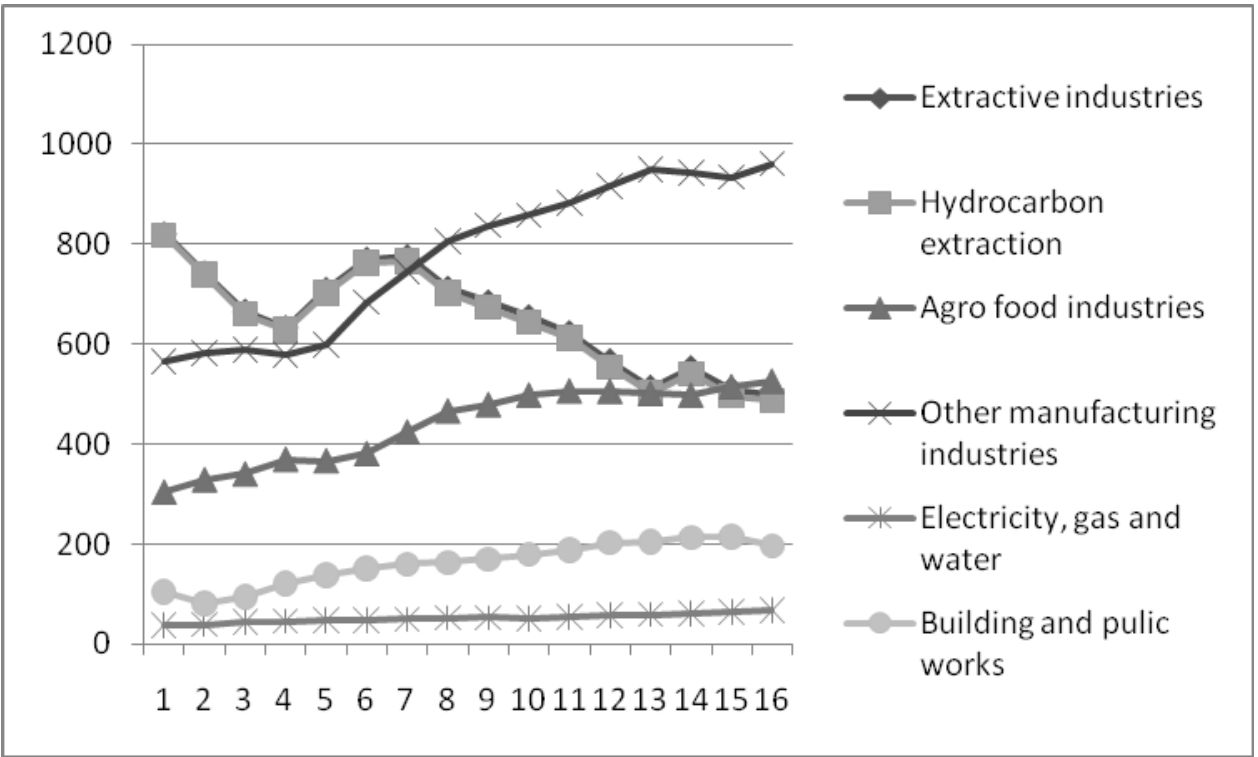

Figure 2. Ventilation of real GDP of the secondary sector $\quad$ (base $100=2000$ )

Source : Constructed by author using data from the NIS (2009)

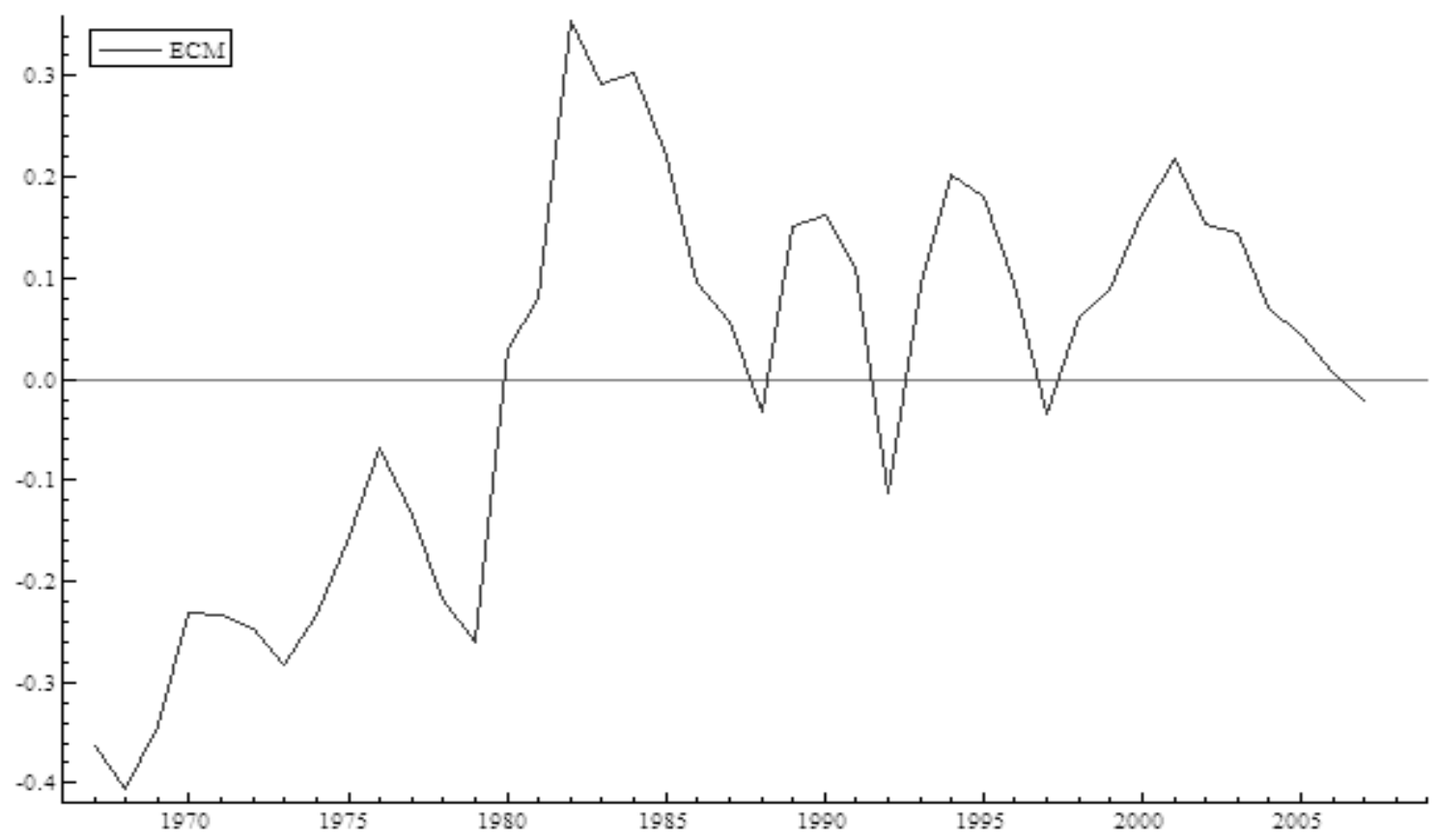

Figure 3. Evolution of estimated residuals.

Source: author's estimations from the World Bank 